ROCZNIKI FILOZOFICZNE

Tom LXVIII, numer $4-2020$

DOI: https://doi.org/10.18290/rf20684-4

ANNA LEMAŃSKA

\title{
KONFLIKT EWOLUCJONIZMU Z KREACJONIZMEM JAKO SPÓR ŚWIATOPOGLĄDOWY
}

Jednym ze współczesnych sporów światopoglądowych jest konflikt między częścią ewolucjonistów a zwolennikami projektu w przyrodzie. Ci pierwsi twierdzą, że ewolucja - naturalny, bezcelowy proces zachodzący w przyrodzie - wyjaśnia w pełni budowę, przystosowania, wielość gatunków i form świata ożywionego, dlatego odwoływanie się do jakichś czynników pozaprzyrodniczych jest niepotrzebne. Skoro zatem do wyjaśnienia zjawisk przyrodniczych wystarczą tylko czynniki naturalne, to Bóg nie jest niezbędny, a więc nie istnieje. Zwolennicy projektu uważają natomiast, że wskazywane przez ewolucjonistów naturalne czynniki i mechanizmy, w szczególności dobór naturalny, nie są w stanie wyjaśnić adekwatnie pochodzenia rozmaitych struktur biologicznych, gdyż dostrzegają w nich zaprojektowanie przez inteligentny czynnik. Zatem musi istnieć projektant, choć nie jest on przez wszystkich zwolenników utożsamiany z Bogiem. Co istotne, obie strony sporu twierdzą, że ich wnioski wynikają z nauk przyrodniczych i mieszczą się w obszarze przyrodoznawstwa. Ta trwająca od końca lat siedemdziesiątych XX wieku' ${ }^{1}$ kontrowersja wyrasta ze starszego sporu między ewolucjonistami a tzw. kreacjonistami naukowymi. I chociaż dyskusje toczą się już od ponad stu lat i przytoczono w nich wiele różnorodnych argumentów ${ }^{2}$,

Prof. dr hab. AnNa LeMaŃSKa - Uniwersytet Kardynała Stefana Wyszyńskiego w Warszawie, Wydział Filozofii Chrześcijańskiej, Instytut Filozofii; e-mail: a.lemanska@uksw.edu.pl; ORCID: https://orcid.org/0000-0002-2531-1919.

${ }^{1} \mathrm{O}$ historii ruchu inteligentnego projektu zob. np. Larry Wiтнам, By Design. Science and the Search for God (San Francisco: Encounter Books, 2003).

${ }^{2}$ Literatura na ten temat jest bardzo obszerna i w artykule nie ma możliwości, by się do niej odnosić. Zaznaczę tylko, że w Polsce oceną argumentów ewolucjonistów, kreacjonistów i zwolenników koncepcji inteligentnego projektu zajmują się m.in.: Kazimierz KLoskowsKi, Filozofia ewolucji i filozofia stwarzania, t. 1-2 (Warszawa: Wydawnictwo ATK, 1999); Kazimierz JoDKowsKI, Spór ewolucjonizmu z kreacjonizmem. Podstawowe pojęcia i poglądy (Warszawa: 
nie widać szans na ich zakończenie i uzyskanie jakiegoś konsensusu. Źródło takiego stanu rzeczy zdaje się leżeć w tym, że spór ten toczy się w rzeczywistości na płaszczyźnie filozoficznej.

W artykule przytaczam argumenty za tym, że zarówno materialistycznie ujmowany ewolucjonizm, jak i koncepcja inteligentnego projektu nie są teoriami naukowymi. Dyskusje między zwolennikami obu stanowisk są stricte filozoficzne i światopoglądowe. Odwoływanie się do wyników nauk przyrodniczych przez obie strony nie sprawia, że te spory czy dyskusje stają się dyskusjami z zakresu nauk przyrodniczych. Moim celem nie jest ocena argumentacji pojawiających się w dyskusjach wokół kreacji i ewolucji, a jedynie wskazanie, że spór ewolucjonistów ze zwolennikami koncepcji inteligentnego projektu nie może być traktowany jako spór naukowy. Jest tak dlatego m.in., że pojęcie kreacji nie jest pojęciem mieszczącym się w obszarze nauk przyrodniczych $\mathrm{z}$ racji jego bezczasowości czy aczasowości. Stwarzanie bowiem jest aktem Stwórcy, który nie jest bytem czasoprzestrzennym. Toteż Jego działania nie mogą stać się przedmiotem nauk przyrodniczych, choć ich skutki, w postaci materialnych układów, dają się badać empirycznie.

Odpowiedź na pytanie o pochodzenie świata, życia, poszczególnych gatunków biologicznych i człowieka można znaleźć w mitologiach a także religiach różnych kultur. W szczególności Biblia kreśli w pierwszych rozdziałach „Księgi Rodzaju” obraz stwarzania ziemi, nieba, słońca, księżyca, roślin, zwierząt i człowieka. Przekaz biblijny nie pozostawia wątpliwości: wszystko jest zależne w swoim istnieniu od Boga. Wraz z powstaniem filozofii zaczęto szukać wyjaśnień pochodzenia poszczególnych organizmów żywych w naturalnych procesach przyrody. M.in. Arystoteles ugruntował, opartą na potocznej, choć niedokładnej, obserwacji koncepcję samorództwa, według której prostsze organizmy żywe powstają spontanicznie z materii nieożywionej pod wpływem ciepła słonecznego oraz na skutek działania in-

Megas, 2007); JoDKowski, „Zasadnicza nierozstrzygalność sporu ewolucjonizm-kreacjonizm”, Przeglad Filozoficzny - Nowa Seria 21, nr 3 (2012): 201-222; Dariusz SAGAN, „Teoria inteligentnego projektu a kreacjonizm", Kwartalnik Filozoficzny 43, nr 2 (2015): 131-150; SAGAN, Metodologiczno-filozoficzne aspekty teorii inteligentnego projektu (Zielona Góra: Instytut Filozofii UZ, 2015); Piotr BYLICA, „Levels of Analysis in Philosophy, Religion, and Science”, Zygon 50, nr 2 (2015): 304-328. doi:10.1111/zygo.12179; BYLICA, Wspótczesny teizm naturalistyczny z punktu widzenia modelu poziomów analizy. Problem działania sfery nadnaturalnej w przyrodzie (Zielona Góra: Instytut Filozofii UZ, 2016); Józef ZoN, „Kiedy «kreacja albo ewolucja» a kiedy «kreacja oraz ewolucja»", w: Ewolucjonizm czy kreacjonizm, red. Piotr Jaroszyński i in. (Lublin: Fundacja Lubelska Szkoła Filozofii Chrześcijańskiej, 2008): 275-302; Anna LemańskA, „Status metodologiczno-epistemologiczny koncepcji inteligentnego projektu", w: Pogranicza nauki. Protonauka - paranauka - pseudonauka, Filozofia przyrody i nauk przyrodniczych 3, red. Józef Zon (Lublin: Wydawnictwo KUL, 2008), 303-315. 
nych ciał niebieskich. Koncepcja samorództwa w specyficzny sposób zinterpretowana została zaakceptowana następnie przez chrześcijaństwo ${ }^{3}$.

Zanegowanie możliwości zachodzenia samorództwa i coraz głębsze wnikanie dzięki mikroskopom w budowę organizmów, w szczególności jednokomórkowców, a także odkrywanie ich ogromnej złożoności oraz dostrzeganie celowego uorganizowania stały się podstawą argumentacji za istnieniem Boga, Stwórcy życia ${ }^{4}$. Takim jest np. argument Williama Paleya, osiemnastowiecznego teologa i filozofa. Przesłanką jego argumentacji jest uporządkowana i celowa budowa oraz funkcjonowanie żywych organizmów ${ }^{5}$.

Jeszcze w XVIII wieku panowało powszechne przekonanie o stałości gatunków biologicznych. Znalazło ono między innymi swój wyraz w klasyfikacji świata roślin i zwierząt Karola Linneusza używanej do dzisiaj. Jednak obserwacje i badania świata organizmów żywych doprowadziły do przełamania idei stałości gatunków i dopuszczenia możliwości przekształcania się poszczególnych struktur biologicznych w inne. W XIX wieku idea ewolucji została zaakceptowana, choć toczone były spory co do mechanizmów tego procesu.

Jedną z pierwszych prac ukazującą ewoluujący świat organizmów żywych była opublikowana w 1809 r. Filozofia zoologii (Philosophie zoologique) Jeana Baptiste'a Lamarcka. Pół wieku później niezależnie od siebie Alfred R. Wallace i Charles Darwin dochodzą do wniosku, że głównym mechanizmem przemian ewolucyjnych jest dobór naturalny ${ }^{6}$. Trzeba podkreślić, że pracę Darwina $O$ powstawaniu gatunków droga doboru naturalnego, czyli o utrzy-

\footnotetext{
${ }^{3} \mathrm{Na}$ temat idei samorództwa i jej przemian, a także stosunku do niej chrześcijaństwa zob. Adam ŚwIEŻyŃski, „Nowożytne przemiany idei samorództwa”, Roczniki Filozoficzne 57, nr 1 (2009): 195-229.

${ }^{4}$ Argumenty na istnienie Boga, których przesłankami były własności świata przyrody, są obecne w myśli chrześcijańskiej od jej początku. Najszerzej znane i dyskutowane są tzw. drogi św. Tomasza z Akwinu.

${ }^{5}$ William Paley w swej Teologii naturalnej z 1802 rozumuje następująco: ponieważ skomplikowany mechanizm zegarka nie mógł powstać przez przypadkowe połączenie części składowych, więc musiał go zaplanować i złożyć zegarmistrz. Podobnie organizmy żywe nie mogły powstać przypadkowo lub tylko na mocy przyczynowości sprawczej przyrody, gdyż są to celowo uorganizowane, złożone i funkcjonalne struktury. Musi zatem istnieć ich Projektant i Twórca William Paley, Natural Theology: or, Evidences of the Existence and Attributes of the Deity, Collected from the Appearances of Nature (Boston: Gould and Lincoln, 1854), 5-8, dostęp 23.12.2019, archive.org/details/naturaltheology01warwgoog.

${ }^{6}$ Praca Alfreda Wallace „On the Tendency of Varieties to Depart Indefinitely from the Original Type" oraz fragmenty nieopublikowanej jeszcze pracy Charlesa Darwina On the Origin of Species i jego listu do Asy Graya zostały zaprezentowane 1 lipca 1858 r. na posiedzeniu Towarzystwa Linneuszowskiego i opublikowane jako artykuł pod tytułem: On the Tendency of Species to form Varieties; and on the Perpetuation of Varieties and Species by Natural Means of Selection w Rocznikach Towarzystwa w sierpniu tego samego roku.
} 
mywaniu sie doskonalszych ras $w$ walce o byt (On the Origin of Species by Means of Natural Selection, or the Preservation of Favoured Races in the Struggle for Life) z 1859 r. należy uznać za pracę z zakresu nauk biologicznych, gdyż po pierwsze, Darwin opierał się na zebranym przez siebie obszernym materiale obserwacyjnym, po drugie, główny mechanizm zmian ewolucyjnych widział $\mathrm{w}$ doborze naturalnym, a więc naturalnym i bezcelowym mechanizmie. Tym samym proces ewolucji stał się przedmiotem badania nauk przyrodniczych.

Dokonania Darwina i innych dziewiętnastowiecznych ewolucjonistów pokazały luki w argumentacjach za istnieniem Boga odwołujących się do celowości żywych organizmów i bazujących na założeniu o stałości gatunków. Co więcej, teoria ewolucji Darwina została wykorzystana do zwalczania religii i do uzasadniania światopoglądu materialistycznego. Musiało to wywołać reakcję ze strony teistów. Niestety, reakcja ta przejawiła się przede wszystkim w ruchach kreacjonistycznych, które przekaz biblijny uznały za tekst przyrodniczy. Tzw. naukowi kreacjoniści próbowali na płaszczyźnie nauk przyrodniczych wykazać, że stwarzanie świata odbywało się tak, jak przedstawia to Księga Rodzaju. Z jej tekstu zaś wynika, że chociaż Bóg stwarzał kolejno: rośliny (dzień trzeci), zwierzęta morskie i ptaki (dzień piąty), zwierzęta lądowe oraz człowieka (dzień szósty), to - ponieważ nie ma tu mowy o przemianach poszczególnych gatunków — nie zachodzi żaden proces ewolucji. Doprowadziło to do wytworzenia mylnego przekonania, że ewolucjonizm i kreacjonizm nie mogą współistnieć.

Obrońcy ewolucjonizmu pokazywali, że kreacjonizm naukowy nie jest nauką, a jedynie doktryną religijną. Skuteczne usunięcie kreacjonizmu naukowego poza obszar nauk przyrodniczych, a także trudności darwinizmu (podnoszone przez samych przyrodników) doprowadziły $\mathrm{w}$ drugiej połowie XX wieku do powstania ruchu inteligentnego projektu. Zwolennicy tej koncepcji nie odrzucają wprost możliwości zachodzenia przemian ewolucyjnych, usiłują natomiast pokazać, że wskazywane przez ewolucjonistów mechanizmy tych przemian nie są w stanie wyjaśnić powstania rozmaitych struktur w przyrodzie, których własności (nieredukowalna złożoność, wyspecyfikowana złożoność) świadczą o tym, że musiały zostać zaprojektowane przez jakiś inteligentny czynnik. $Z$ kolei sformułowany niedawno ruch nowego ateizmu ${ }^{7}$ wykorzystuje przyrodnicze teorie ewolucji do zwalczania religii.

\footnotetext{
${ }^{7}$ Główne założenia i historię ruchu można znaleźć w: Piotr Gutowski, „Czym jest «nowy ateizm»", w: Nauki przyrodnicze a nowy ateizm, red. Marek Słomka (Lublin: Wydawnictwo KUL, 2012): 7-45.
} 
Obecnie zatem mamy do czynienia z następującym stanem rzeczy. Materialiści wykorzystują neodarwinizm i syntetyczną teorię ewolucji w argumentacjach za nieistnieniem Boga ${ }^{8}$. Zwolennicy projektu zaś poszukują śladów Boga w przyrodzie, negując jednocześnie zachodzenie procesu tzw. makroewolucji ${ }^{9}$. W konsekwencji istnieją dwa zwalczające się obozy, niejako okopane na swych pozycjach. Co istotne, zarówno ateistyczni ewolucjoniści, jak i zwolennicy projektu twierdzą, że spór między nimi toczy się na płaszczyźnie nauk przyrodniczych i że wyniki nauk przyrodniczych są w stanie ten spór rozstrzygnąć na korzyść jednej ze stron.

Ten stan rzeczy nie jest komfortowy dla tych teistów, którzy są przekonani o zachodzeniu procesu ewolucji w przyrodzie, toteż próbują wyjść $\mathrm{z}$ tego impasu, przyjmując różne strategie. Jedną z nich jest uznanie, że płaszczyzny, na których rozpatruje się ewolucję i kreację, są odmienne i niesprowadzalne do siebie, toteż nie może między nimi istnieć konflikt ${ }^{10}$. Z kolei Pierre Teilhard de Chardin stworzył wizję ewoluującej przyrody, która swe źródło i cel ma $\mathrm{w}$ Bogu ${ }^{11}$. Podobne rozwiązania przyjmują inni filozofowie, którzy łączą ze sobą ewolucjonizm i kreacjonizm, tworząc koncepcje ewolucyjnego kreacjonizmu lub teistycznego ewolucjonizmu, pokazując tym samym, że między ewolucjonizmem a kreacjonizmem nie ma logicznej sprzeczności ${ }^{12}$.

Jak to już stwierdziłam, znaczna część trudności z uzyskaniem konsensusu między ewolucjonistami a kreacjonistami jest związana $\mathrm{z}$ tym, że obie strony sporu nie przyjmują do wiadomości, że płaszczyzna nauk przyrodniczych nie jest właściwa dla tego typu dyskusji. Spór między ewolucjonistami a zwolennikami projektu jest $\mathrm{w}$ istocie sporem światopoglądowym i jako taki mieści się na płaszczyźnie filozoficznej, a nie nauk przyrodniczych. Dzieje się tak dlatego, że metoda nauk przyrodniczych, jaką jest metoda ekspery-

\footnotetext{
${ }^{8}$ Czynią tak m.in. Richard Dawkins, Daniel Dennett, Sam Harris, Christopher Hitchens, Victor J. Stenger.

${ }^{9}$ Zwolennicy projektu, w przeciwieństwie do kreacjonistów naukowych, przyjmują, że mogą następować przemiany ewolucyjne w obrębie gatunku. Jest to mikroewolucja, dzięki której powstają nowe odmiany czy rasy. Natomiast makroewolucja, czyli powstawanie nowych jednostek systematycznych związane z dużymi zmianami planów budowy, ich zdaniem, nie zachodzi.

${ }^{10}$ Spór ewolucjonizmu z kreacjonizmem jest egzemplifikacją szerszego sporu między naukami przyrodniczymi a religią. Próbą przezwyciężenia konfliktu jest w szczególności koncepcja dwóch nieprzenikających się magisteriów (tzw. NOMA), restrykcyjnie rozdzielająca nauki przyrodnicze od religii, zaproponowana przez: Stephen J. Gould, Rocks of Ages. Science and Religion in the Fullness of Life (London: Vintage, 2001).

${ }^{11}$ Pierre TeILHARD De Chardin, Le phénomène humain (Paris: Éditions du Seuil, 1955).

${ }^{12}$ W Polsce koncepcje łączące ewolucjonizm z kreacjonizmem tworzyli: Kazimierz Kłósak, Tadeusz Wojciechowski, Szczepan W. Ślaga, Kazimierz Kloskowski, Józef Życiński, Michał Heller.
} 
mentalna, nakłada ograniczenia na to, co i w jaki sposób może być przez nie badane. $Z$ tego powodu przedmiotem badania nauk przyrodniczych jest to wszystko, co bezpośrednio lub pośrednio jest obserwowalne, mierzalne bądź empirycznie testowalne. Kazimierz Kłósak mówi w tym kontekście o zjawiskach $^{13}$. Warto dodać, że takie określenie przedmiotu nauk przyrodniczych doprowadza Kłósaka do uznania, że teorie z zakresu nauk przyrodniczych ani nie opierają się na założeniach filozoficznych, ani nie wynikają z nich żadne wnioski natury filozoficznej ${ }^{14}$. Zachodzące zjawiska wyjaśnia się zaś przez wskazanie przyczyn mieszczących się w obrębie przyrody. Przyczyny nadprzyrodzone, pozanaturalne wymykają się metodzie eksperymentalnej, m.in. $\mathrm{z}$ tego powodu, że nie można ani ich wywoływać, ani na nie wpływać ${ }^{15}$.

$\mathrm{Na}$ płaszczyźnie nauk przyrodniczych dostrzegane w przyrodzie przeobrażenia, różnorodność żywych organizmów, ich przystosowania do środowiska itp. najprościej jest wyjaśnić, przyjmując, że żaden organizm, żadna struktura w przyrodzie nie jest statyczna, ale może, a nawet musi się zmieniać. Oznacza to, że w przyrodzie zachodzą procesy ewolucji ${ }^{16}$. Stwierdzając fakt zmienności, przyrodnik następnie poszukuje jego mechanizmów. Współcześnie wyjaśnia się zachodzenie procesu ewolucji przez odwołanie do mutacji, rekombinacji, doboru naturalnego, dryfu genetycznego, dziedziczenia epigenetycznego itp. Są to mechanizmy naturalne i choć ciągle biolodzy nie są zgodni co do znaczenia tych poszczególnych czynników i ich roli w procesie ewolucji, to zgadzają się co do tego, że wyjaśnienia procesów ewolucyjnych na płaszczyźnie nauk przyrodniczych nie mogą odwoływać się do jakichś przyczyn pozanaturalnych. W tym miejscu jednak należy wyraźnie podkreślić, że wbrew temu, co twierdzą ateistyczni ewolucjoniści, nie jest to równoznaczne $\mathrm{z}$ tym, że takie czynniki pozaempiryczne na pewno nie

\footnotetext{
${ }^{13}$ Por. Kazimierz KŁósAK, $Z$ teorii i metodologii filozofii przyrody (Poznań: Księgarnia Św. Wojciecha, 1980), 20.

${ }^{14}$ Tamże, 14-22.

${ }^{15} \mathrm{Na}$ nieprzydatność wyjaśnień wskazujących na przyczyny pozanaturalne zwraca uwagę np. Mark IsAAK w artykule „A Philosophical Premise of 'Naturalism'?”, talkdesign.org, 24.09.2002, dostęp 15.01.2010, talkdesign.org/faqs/naturalism.html. Stwierdza on, że wyjaśnienia odwołujące się do sfery nadprzyrodzonej są nie tyle błędne, co nieużyteczne.

${ }^{16}$ Jak stwierdził Theodosius Dobzhansky, ,nic w biologii nie ma sensu bez światła ewolucji, sub specie evolutionis. Jeżeli świat ożywiony nie powstał ze wspólnych przodków na drodze procesów ewolucyjnych, to fundamentalna jedność żyjących organizmów jest mistyfikacją a ich różnorodność żartem" (nothing makes sense in biology except in the light of evolution, sub specie evolutionis. If the living world has not arisen from common ancestors by means of an evolutionary process, then the fundamental unity of living things is a hoax and their diversity is a joke) Theodosius Dobzhansky, „Biology, Molecular and Organismic”, American Zoologist 4, nr 4 (1964): 449.
} 
istnieją. Z tego, że poszukuje się wyjaśnień naturalnych, wynika tylko tyle, że jeżeli czynniki pozanaturalne istnieją i działają $\mathrm{w}$ przyrodzie, to nie są wykrywalne metodami nauk przyrodniczych.

$\mathrm{Z}$ powyższą tezą nie zgadzają się zwolennicy koncepcji inteligentnego projektu, którzy uważają, że można wykryć projekt w przyrodzie metodami charakterystycznymi dla nauk przyrodniczych. Michael Behe w tym celu wprowadza pojęcie układu nieredukowalnie złożonego. Jest nim „pojedynczy system, złożony z kilku dobrze dopasowanych, oddziałujących ze sobą części, którym przypisuje się podstawowe funkcje, gdzie usunięcie jakiejkolwiek z tych części powoduje, że system przestaje sprawnie funkcjonować" ${ }^{17}$. Twierdzi zatem, że taki układ musiał być zaprojektowany przez inteligentny czynnik, nie mógł bowiem powstać z jakichś prostszych, wyjściowych form przez kumulowanie się drobnych zmian przystosowawczych na skutek działania doboru naturalnego, gdyż nie istnieją własności i funkcje, które dobór mógłby selekcjonować. Behe dopatrzył się układów nieredukowalnie złożonych w wici bakteryjnej, rzęskach, kaskadzie krzepnięcia krwi ${ }^{18}$.

William A. Dembski uważa, że o zaprojektowaniu jakiegoś obiektu świadczy jego wyspecyfikowana złożoność. Złożoność zapewnia bardzo małe prawdopodobieństwo przypadkowego powstania takiego układu, natomiast specyfikacja, czyli istnienie w układzie pewnego rodzaju wzorca, będzie świadczyć o zaprojektowaniu przez inteligentny czynnik. Dembski proponuje stosowanie swego rodzaju algorytmu, nazwanego filtrem eksplanacyjnym (explanatory filter) ${ }^{19}$, który miałby pozwolić odróżnić obiekty, które powstały w sposób naturalny, od tych, które zostały zaprojektowane.

Nieredukowalna złożoność bądź wyspecyfikowana złożoność, według zwolenników koncepcji inteligentnego projektu, stanowią kryteria, dzięki którym na płaszczyźnie badawczej nauk przyrodniczych daje się wykryć ślady pozostawione przez inteligentnego projektanta. Poszukuje się zatem takich układów biologicznych, które są nieredukowalnie złożone bądź wyspe-

\footnotetext{
${ }^{17}$ Michael BeHE, „Precyzyjny projekt: powstawanie biologicznych mechanizmów molekularnych", thum. Dariusz Sagan (Na Początku..., nr 5-6 (2004): 172, dostęp 10.09.2019, http://www. nauka-a-religia.uz.zgora.pl/index.php/pl/przedruki/15-przedruki/391-pr-art-15.

${ }^{18}$ Zob. Michael BeHE, Darwin's Black Box: The Biochemical Challenge to Evolution (New York: Free Press, 1996); BeHE, „Molecular Machines: Experimental Support for the Design Inference", Cosmos Pursuit 1, nr 2 (1998): 27-35; BeHE, "Design in the Details: The Origin of Biomolecular Machines", w: Darwinism, Design and Public Education, red. John A. Campbell, Stephen C. Meyer (East Lansing, MI: Michigan State University Press, 2003), 287-302.

${ }^{19}$ William Dembski, The Design Inference: Eliminating Chance through Small Probabilities (Cambridge: CUP, 1998), 36-47; DemBski, No Free Lunch: Why Specified Complexity Cannot Be Purchased without Intelligence (Lanham: Rowman \& Littlefield Publishers, 2002), 12-15.
} 
cyfikowane. Jeżeli takie układy istnieją, to musi również istnieć inteligencja, która je zaprojektowała ${ }^{20}$. Ponieważ sposób oceny, czy dany układ jest nieredukowalnie złożony lub specyficzny, znajduje się, zdaniem zwolenników koncepcji, w obszarze metod nauk przyrodniczych, to wniosek o istnieniu inteligentnego projektanta również jest wnioskiem naukowym. Prowadzi to do uznania, że nauki przyrodnicze są w stanie wykazać jego istnienie, a koncepcja inteligentnego projektu jest teorią naukową.

Sprawa nie jest jednak tak oczywista, jak twierdzą zwolennicy projektu. Główną wadą wskazywanych kryteriów jest to, że pozwalają co najwyżej znaleźć takie układy, których powstania nie wyjaśnia dobór naturalny. Nie oznacza to jednak, że nie mogły powstać w wyniku procesów ewolucyjnych. Nie mamy bowiem do czynienia tylko z dwiema możliwościami: albo dobór naturalny, albo inteligentny projektant. Co więcej, kluczowe dla rozpoznania projektu pojęcia specyfikacji i nieredukowalnej złożoności nie są pojęciami empirycznymi, operacyjnymi. Uznanie bowiem jakiegoś układu za specyficzny bądź nieredukowalnie złożony odbywa się na podstawie aktualnej, nie zawsze pełnej, wiedzy o tym układzie. Może zatem okazać się, i często tak się dzieje w przykładach wskazywanych przez zwolenników inteligentnego projektu, że to brak dostatecznej informacji o układzie uniemożliwia stwierdzenie, że dana struktura powstała na drodze naturalnych procesów. Rozpoznanie zaś wzorca $w$ danym układzie jest subiektywne, gdyż to badacz, niejako a priori, określa, co może być uznane za ten wzorzec. Toteż ocena, że jakiś układ biologiczny jest nieredukowalnie złożony lub wyspecyfikowany, opiera się na intuicji badacza, a nie na obiektywnych kryteriach. Pośrednio stwierdza to sam Dembski, pisząc: „łatwo jednak intuicyjnie rozróżnić wzorce, które implikują projekt, od tych, które go nie implikują" ${ }^{21}$. Dembski odwołuje się zatem do intuicji, a nie do obiektywnych kryteriów eksperymentalnych, niezależnych od subiektywnych wyobrażeń przyrodnika o projekcie. Na subiektywność pojęcia wyspecyfikowanej złożoności zwraca uwagę Kazimierz Jodkowski ${ }^{22}$.

Pojęcie inteligentnego działania również nie jest pojęciem jednoznacznym ani operacyjnym, gdyż nie ma obiektywnej metody „zmierzenia” lub

\footnotetext{
${ }^{20}$ Jak stwierdza Michael BeHE: „Jeśli rzęska nie mogła być wytworzona przez dobór naturalny, to ta rzęska musiała być zaprojektowana” — „Precyzyjny projekt”, 176.

${ }^{21}$ William DemBsкI, „Powrót projektu do nauk przyrodniczych”, tłum. Dariusz Sagan, w: Teoria inteligentnego projektu, red. Kazimierz Jodkowski (Warszawa: Megas, 2007), 18.

${ }^{22}$ Kazimierz JodKowski, „Czy nauka może wykryć inteligentny projekt?”, filozofiaprzyrody.pl, 30.12.2019, dostęp 3.01.2020, https://www.filozofiaprzyrody.pl/czy-nauka-moze-wykrycinteligentny-projekt.
} 
zaobserwowania inteligencji. Metody stosowane na przykład w kryminalistyce czy archeologii nie mogą być wykorzystywane do poszukiwania projektu w przyrodzie wbrew temu, co twierdzą zwolennicy projektu. Metody te stosuje się z powodzeniem $\mathrm{w}$ tych dziedzinach, gdyż przyjmuje się założenie o istnieniu ludzi, którzy mogli pozostawić określone ślady. Znaleziony na wrzosowisku zegarek rzeczywiście będzie świadczył o tym, że zostawił go tu człowiek. Ten wniosek jednak zostaje uzyskany na podstawie wcześniejszej wiedzy o tym, co to są zegarki, do czego służą, że zegarki produkują ludzie. Jeżeli natomiast zaobserwuje się coś nieznanego, to nie ma kryteriów pozwalających jednoznacznie stwierdzić, czy to coś jest bądź nie jest dziełem inteligentnego czynnika.

Zwolennicy koncepcji projektu - aby nie być posądzonymi o religijne odniesienia - nie wskazują bezpośrednio kandydata na projektanta, a tylko wnioskują pośrednio, na podstawie ,śladów” jakoby przez niego pozostawionych, o jego istnieniu. Wskazywanie na projekt na płaszczyźnie przyrodniczej wymusza jednak pytania o naturę projektanta, o to, czym lub kim jest, jakie ma własności, gdzie się znajduje, w jaki sposób utworzył dane struktury, jak sam powstał. Pozostawiając te pytania bez odpowiedzi, zwolennicy koncepcji inteligentnego projektu dają podstawy do przypuszczenia, że istnienie inteligentnego projektanta jest przyjmowane przez nich na początku jako założenie, które następnie próbują uzasadnić. Projekt i celowość w przyrodzie nie są zatem rozpoznawane metodami nauk przyrodniczych. Interpretacja $\mathrm{w}$ kategoriach projektu jest dokonywana na płaszczyźnie filozoficznej. Argumenty podawane przez zwolenników koncepcji inteligentnego projektu są argumentami filozoficznymi, a nie naukowymi.

Z kolei materialiści, wyciągając wniosek o nieistnieniu Boga, zakładają naturalizm ontologiczny nauk przyrodniczych, przyjmując mianowicie, że istnieje tylko to, co może być przedmiotem badania tych nauk. Jest to jednak założenie tożsame ze stanowiskiem materializmu, a nie wniosek wynikający z jakichś teorii przyrodniczych.

Zwolennicy koncepcji inteligentnego projektu oraz ateistyczni ewolucjoniści nie wykazali zatem, że uzasadnienie ich stanowisk odbywa się na płaszczyźnie nauk przyrodniczych. Wprawdzie w argumentacjach obie strony sporu używają danych naukowych, to jednak ich główne przesłanki mają charakter filozoficzny oraz ideologiczny. Spór zatem odbywa się na płaszczyźnie filozoficznej bądź szerzej światopoglądowej. Ma to istotne znaczenie, gdyż na płaszczyźnie filozoficznej nie można spodziewać się jednoznacznego rozstrzygnięcia kontrowersji na korzyść jednej ze stron. Przyj- 
mowane bowiem rozwiązania w istotny sposób zależą od założeń o charakterze filozoficznym. Również próby łączenia ewolucjonizmu z kreacjonizmem odbywają się na płaszczyźnie filozoficznej i proponowane koncepcje mają charakter filozoficzny. Nie oznacza to jednak, że argumenty zaczerpnięte z nauk przyrodniczych nie mają żadnego znaczenia. Nauki przyrodnicze dostarczają informacji o budowie i funkcjonowaniu rozmaitych struktur i układów istniejących w przyrodzie, w tym biologicznych. Dzięki temu obraz otaczającej człowieka rzeczywistości może być oczyszczany z błędnych mniemań, np., że Ziemia jest płaska, czy że myszy i muchy spontanicznie powstają z materii nieożywionej. Jednocześnie nowe odkrycia naukowe, burzące stary obraz świata, mogą stać się wyzwaniem dla wierzeń religijnych, a także koncepcji filozoficznych, dla których tłem była przestarzała z punktu widzenia współczesnej wiedzy wizja świata.

W dyskusjach między kreacjonistami a ewolucjonistami często pomija się analizę dwóch kluczowych pojęć, a mianowicie ewolucji i kreacji, a także ich zasadniczo odmienne odniesienia do czasu i przestrzeni. Termin „ewolucja” ogólnie oznacza proces zmian, z reguły postępowych. Toteż mówi się o ewolucji np. Wszechświata, gwiazd, społeczeństw, gatunków biologicznych. Jest używany w naukach przyrodniczych, społecznych, filozofii, teologii, choć w każdym z tych obszarów może mieć nieco inne znaczenie. Należy o tym pamiętać, gdy rozpatrując proces ewolucji, przechodzi się z płaszczyzny nauk przyrodniczych na płaszczyznę filozoficzną. Również w biologii ewolucja jest różnie określana i może oznaczać:

a) proces przekształcania się organizmów w zmieniającym się środowisku; w jego wyniku powstają i utrwalają się w ciągu pokoleń nowe, dziedziczne cechy przystosowawcze, następuje zróżnicowanie się populacji i wyodrębnianie nowych gatunków;

b) nieodwracalne przemiany świata organizmów zachodzące w geologicznej skali dziejów Ziemi ${ }^{23}$;

c) zmiany cech całych grup organizmów następujące z biegiem pokoleń ${ }^{24}$;

d) ,jednokierunkowy, nieodwracalny, przebiegający w czasie proces, który urzeczywistniając się, przynosi nowość, różnorodność i wyższe szczeble organizacji materii",25;

\footnotetext{
${ }^{23}$ Jerzy DzIK, Ewolucja (Warszawa 2006), 4, dostęp 15.01.2020, http://www.paleo.pan.pl/ people/Dzik/Publications/Ewolucja_liceum.pdf.

${ }^{24}$ Douglas Futuyma, Ewolucja (Warszawa: Wydawnictwo UW, 2008), 2.

${ }^{25}$ Sol Tax, Charles Callender, red., Evolution after Darwin, t. 3, Issues in Evolution (Chicago: University of Chicago Press, 1960), 107.
} 
e) kierunkowe, nieodwracalne zmiany w czasie cech pewnej szczególnej klasy samopowielających się obiektów - replikatorów ${ }^{26}$.

Wprawdzie te określenia wyrażają podobną ideę, to wskazuje się w nich na nieco odmienne aspekty procesu ewolucji biologicznej. We wszystkich jednak jest podkreślane to, że ewolucja jest toczącym się w czasie procesem.

Termin „kreacja”, poza „technicznym” użyciem w fizyce kwantowej, odnosi się do działania Boga, jest zatem pojęciem teologicznym lub filozoficznym. Termin ten również ma różne znaczenia. Można go rozumieć np. jako:

a) kreację bezpośrednią,

b) kreację pośrednią, zakładającą współdziałanie Boga z przyczynami naturalnymi,

c) creatio continuиa.

Kreacjonizm bezpośredni przyjmuje, że Bóg ingeruje w przyrodę w określonym miejscu i czasie, stwarzając np. poszczególne organizmy czy gatunki. W kreacjonizmie pośrednim przyjmuje się $\mathrm{z}$ reguły bezpośrednie stworzenie rzeczywistości przyrodniczej przez Boga, a następnie już pośrednie działanie Boga przez prawa przyrody. Toteż powstanie nowych struktur biologicznych nie wymaga bezpośredniej ingerencji Boga w przyrodę. Z kolei koncepcja creatio continua nie sprowadza działania Boga do jakichś bezpośrednich ingerencji $\mathrm{w}$ przyrodę $\mathrm{w}$ określonym miejscu i czasie, ale nie wykluczając możliwości takich ingerencji, przyjmuje, że Bóg niejako jest stale obecny w historii kosmosu i człowieka.

Należy podkreślić, że kreacja jako czynność Boga nie jest umiejscowionym czasoprzestrzennie zdarzeniem, zatem nie jest ani zjawiskiem, ani procesem. Dotyczy to zarówno stworzenia z nicości całej rzeczywistości materialnej, jak i poszczególnych zawartych w niej obiektów fizycznych. Akt kreacji jest poza czasem i przestrzenią, choć jego skutek może być elementem przyrody i jako taki jest umiejscowiony w czasie i przestrzeni.

Pojęcia ewolucji i kreacji mają zatem odmienne odniesienia do czasu i przestrzeni. Ponieważ nauki przyrodnicze zajmują się tylko tym, co jest czasowe i przestrzenne, to proces ewolucji może być badany w naukach przyrodniczych, zarazem może również być przedmiotem badania filozofii, natomiast ani kreacja, ani Projektant nie mogą stać się przedmiotem badania nauk przyrodniczych, gdyż Bóg jest aczasowy i aprzestrzenny. W tym przypadku tylko płaszczyzny filozoficzna i religijna są właściwe. Jest to dodatkowy argument na korzyść tezy, że spór ewolucjonizmu z kreacjonizmem toczy się w rzeczywistości na płaszczyźnie filozoficznej, a nie nauk przyrodniczych.

\footnotetext{
${ }^{26}$ Richard DAwkins, Samolubny gen (Warszawa: Prószyński i S-ka, 1996).
} 
Nauki przyrodnicze nie mają narzędzi, by rozstrzygać, czy zdarzenie (a więc coś umiejscowionego w czasie i przestrzeni) bądź jakiś obiekt przyrodniczy jest efektem działania Bytu spoza świata przyrody. Mogą tylko, w sytuacji, gdy nie ma naturalistycznego wyjaśnienia ich genezy, wskazać na to, że przy aktualnym stanie wiedzy przyrodniczej nie można określić ich pochodzenia. Natomiast w filozofii i teologii są „narzędzia”, by ewentualną ingerencję Boga w przyrodzie rozpoznać, gdyż jest tu uprawomocnione rozpatrywanie relacji Boga do stworzonego świata.

Dyskusje między kreacjonistami a ewolucjonistami są prowadzone w języku, w którym są odniesienia do czasu i przestrzeni. Czas i przestrzeń bowiem są elementem przyrody, a wszystko, co istnieje w rzeczywistości materialnej, jest związane $\mathrm{z}$ czasem i przestrzenią. Zgodnie $\mathrm{z}$ obecnym stanem wiedzy z zakresu fizyki czas, przestrzeń, materia i energia są powiązane ze sobą, wzajemnie na siebie oddziałują, nie można ich fizycznie oddzielić. Tworzą jedną strukturę. Czasowość i przestrzenność są dwiema immanentnymi cechami przyrody, są własnościami wszystkich przedmiotów materialnych i warunkują ich materialność. Jako byt materialny człowiek jest elementem tej struktury. Jest w pewnym sensie zamknięty w czasoprzestrzeni, z której nie może się wyzwolić. Toteż cały aparat poznawczy człowieka (zmysły, mózg przetwarzający informacje) rozpoznaje rzeczywistość, umieszczając ją w ramach przestrzenno-czasowych. Człowiek nie jest w stanie wyobrazić sobie czegoś, co jest poza przestrzenią i poza czasem. Dlatego odniesień do czasu i przestrzeni nie daje się usunąć z języka. Stwarza to istotne trudności przy interpretacji procesu ewolucji oraz kreacji. Ewolucja jest ze swej istoty procesem rozciągniętym w czasie, procesem historycznym, a także zależnym od miejsca, gdyż środowisko w istotny sposób wpływa na jej przebieg. Natomiast akt kreacji jest pozaczasowy, gdyż Bóg jest bezczasowy, jest wieczny czy wiekuisty, nie jest także umiejscowiony przestrzennie. Toteż nie można do Niego odnosić żadnych określeń związanych z czasem i przestrzenią. Ta aczasowość Boga jest jednak dla nas, ludzi, bytów zanurzonych w czasie i ograniczonych czasowo, bardzo trudna do ujęcia i zrozumienia. Brakuje również określeń, ponieważ te, które są odnoszone do Boga — wieczny, wiekuisty, to, że dla Niego istnieje tylko ciągłe teraz nie są do końca adekwatne, gdyż w jakiś sposób odnoszą się do kategorii czasowych $^{27}$. Problem powstaje również przy rozpatrywaniu relacji przyczyna-

\footnotetext{
${ }^{27}$ Wnikliwą analizę relacji czasu i wieczności z punktu widzenia teologii, filozofii i nauk przyrodniczych przeprowadza: Antje JACKELÉN, Time and Eternity. The Question of Time in Church, Science, and Theology (Philadelphia-London: Templeton Foundation Press, 2005).
} 
skutek w sytuacji, gdy chodzi o Boga jako przyczynę sprawczą. Relacja przyczyna-skutek zakłada bowiem następstwo czasowe. Stanowi to zasadniczą trudność dla prób ujęcia relacji Boga do świata, Jego transcendencji i immanencji.

Często, zwłaszcza w potocznym rozumieniu, wieczność jest traktowana jako trwanie niemające początku i końca. Przy takim rozumieniu zakłada się jednak milcząco jakiś upływ czasu, co nieuchronnie prowadzi do uwikłania w paradoksy. Aby uniknąć paradoksów, św. Augustyn przeciwstawia wieczność czasowi w następujący sposób: „Gdyby ktoś ujął ich myśl, uspokoił ją i nadał jej stałość choćby na krótką chwilę, to przynajmniej w owej chwili ujrzeliby blask zawsze spokojnej wieczności. Porównaliby ją z czasem, który nigdy nie stoi w miejscu, i przekonaliby się, że jest ona od czasu zupełnie odmienna. Zrozumieliby, że czas zawdzięcza swą długość tylko wielkiej ilości ruchów, które jeden po drugim przemijają, gdyż nie mogą wszystkie istnieć jednocześnie. W wieczności zaś nic nigdy nie przemija, lecz wszystko jest obecne. Żaden zaś czas nie jest cały teraźniejszością. Każdą przeszłość przegania przyszłość biegnąca za nią w trop"28. Boecjusz określa wieczność jako całe naraz i doskonałe posiadanie bezkresnego życia. Jest to trwanie bytu wykluczające początek i koniec oraz wszelkie zmiany. Grzegorz z Nazjanzu zaś stwierdza, że wiekuistość nie jest czasem ani częścią czasu, ani nie może być mierzona ${ }^{29}$. Podobnie św. Tomasz mówi o bezkresności, czyli braku początku i końca oraz jednoczesności istnienia całości bytu; jest tu wykluczone następstwo jakichkolwiek stanów. Toteż i akt stwórczy, według św. Tomasza, wykracza poza czas, przestrzeń, świat, zachodzi poza czasoprzestrzenią, jest ahistoryczny, nie podlega żadnym zmianom czasu i miejsca ${ }^{30}$.

$\mathrm{Z}$ tego punktu widzenia dla kreacjonizmu bezpośredniego problemem staje się sposób działania Boga w przyrodzie. Wszystko, co zdarza się w świecie fizycznym, dzieje się w czasie i przestrzeni. Zatem też skutki bezpośrednich ingerencji Boga w przyrodzie są umiejscowione w czasie i przestrzeni. Kreacjonizm bezpośredni (również w wersji inteligentnego projektu) prowadzi do obrazu Boga, który od czasu do czasu w jakimś miejscu wszechświata interweniuje, stwarzając daną strukturę. Jest to obraz trudny do zaakceptowania, gdyż jest to obraz Boga, który niejako „obserwuje” to, co dzieje się $\mathrm{w}$ przyrodzie zgodnie $\mathrm{z}$ naturalnymi prawami przyrody, nadanymi zresztą

\footnotetext{
${ }^{28}$ Augustyn, Wyznania, 11,11, thum. Zygmunt Kubiak (Warszawa: Pax, 1978), 225-226.

${ }^{29}$ Olaf Pedersen, The Book of Nature (Vaticano: Vatican Observatory Publications, 1992), 32.

${ }^{30}$ Św. Tomasz, Summa theologiae, I q. 10 a. 1.
} 
przyrodzie przez Niego, i który w jakimś momencie „wkracza” w przyrodę, powodując zaistnienie danego układu. Takie wyobrażenie Boga wydaje się trudne do przyjęcia, gdyż Jego działanie zbytnio przypomina działanie ludzkie. Prowokuje to do postawienia pytania: czy Bóg nie mógł na początku nadać przyrodzie takich praw, by doprowadziły one do powstania poszczególnych struktur już bez Jego bezpośredniej interwencji? Łatwiejszy do przyjęcia jest obraz Boga, który nie musi ingerować w rozwój przyrody bezpośrednio, ale jest stale obecny $\mathrm{w}$ historii, która rozwija się zgodnie $\mathrm{z}$ własnym naturalnym biegiem ${ }^{31}$. Toteż wydaje się, że zarówno kreacjonizm pośredni, jak i koncepcja creatio continua lepiej oddają relację Boga do świata.

Otwiera to nowe możliwości interpretacji procesów ewolucyjnych $\mathrm{z}$ jednej strony, z drugiej zaś tworzenie koncepcji filozoficznych łączących kreacjonizm (teizm) z ewolucjonizmem. Ponieważ dla Boga cała rzeczywistość materialno-czasowo-przestrzenna jest $\mathrm{Mu}$ dana cała na raz, to dla Niego ewolucja nie istnieje jako proces. Może natomiast być potraktowana jako swoista chwila aktu stworzenia ${ }^{32}$ czy interpretowana jako realizacja creatio continua $^{33}$. W tym sensie ewolucja i wszelkie procesy emergentne byłyby realizacją czasoprzestrzenną twórczej mocy Boga. Kreacja zatem z ludzkiego punktu widzenia byłaby ciągle trwającym, niezakończonym procesem, a działanie Boga dla człowieka byłoby rozciągnięte w czasie. Natomiast z Boskiej perspektywy, być może, proces ewolucji jest „zwinięty” do aktu creatio ex nihilo świata materialnego. Przy wyjaśnianiu pochodzenia bytów w przyrodzie zatem z jednej strony można odwołać się do naturalnych czynników, na które wskazują teorie ewolucji, z drugiej strony na płaszczyźnie filozoficznej wskazywać na transcendentną Przyczynę, która również jest Stwórcą czasu i przestrzeni. Wbrew pozorom ta dwuaspektowość nie jest

\footnotetext{
${ }^{31}$ Zauważył to jeszcze w połowie XIX wieku Robert Chambers, stwierdzając, ,że jeśli istnieje możliwość wyboru między bezpośrednim stworzeniem a zastosowaniem powszechnych praw ustanowionych przez Stworzyciela, to druga opcja jest bardziej prawdopodobna, gdyż zakłada znacznie wznioślejszą wizję Bożej mocy i godności niż pierwsza" — Robert J. BERRY, Bóg i biolog. Wiara a nauki przyrodnicze, tłum. Jerzy Kochanowicz (Kraków: WAM, 2005), 51-52.

${ }^{32}$ Hoimar von Ditfurth stawia tezę, że „ewolucja jest identyczna z chwilą aktu stworzenia, że ewolucja kosmiczna i biologiczna stanowią w naszych mózgach projekcje dzieła stworzenia, że historia rozwoju przyrody nieożywionej i ożywionej jest formą, z jakiej «od wewnątrz» przeżywamy stworzenie, które «od zewnątrz», z perspektywy transcendentalnej, a więc naprawdę, jest dziełem jednej chwili" - Ditfurth von Hoimar, Nie tylko z tego świata jesteśmy. Nauki przyrodnicze, religia i przyszłość człowieka, thum. Anna Danuta Tauszyńska (Warszawa: Pax, 1985), $137-138$.

33 „Evolution is just a name for continuous creation” - James P. MACKEY, Christianity and Creation: The Essence of the Christian Faith and Its Future Among Religions (New York: Continuum, 2006), 34.
} 
źródłem niespójności, ale stwarza możliwość łącznego ujęcia ewolucji i kreacji w jedną koncepcję stwarzania. W tej perspektywie nie ma żadnej kontrowersji między ewolucją i kreacją. Można powiedzieć, że Bóg działa poprzez ewolucję, niejako „ukrywając” swą obecność i działanie za procesami naturalnymi. Niemniej warto dodać, że z powodu ludzkiego uwikłania w czas i w przestrzeń człowiek nie jest w stanie określić sposobu działania Boga w świecie, dlatego pozostanie to tajemnicą.

Spór między ewolucjonizmem a kreacjonizmem nie dotyczy w istocie tego, w jaki sposób powstały struktury biologiczne; czy powstały jako skutek naturalnych procesów ewolucyjnych, czy nadzwyczajnej ingerencji Stwórcy. Jest to spór między ateizmem a teizmem, czyli jest to spór światopoglądowy i jako taki jest nierozstrzygalny na płaszczyźnie filozoficznej. Tym bardziej nie jest sporem, w którym rozstrzygnięcia można byłoby się spodziewać na płaszczyźnie nauk przyrodniczych. Przyrodnicy zgodnie ze standardami metody eksperymentalnej poszukują wyjaśnienia obserwowanej bioróżnorodności. Znajdują je w mechanizmach procesu ewolucji. Nie jest to równoznaczne $\mathrm{z}$ jednoczesnym zanegowaniem istnienia jakichś przyczyn pozanaturalnych. $\mathrm{Z}$ ewolucjonizmu traktowanego jako koncepcja mieszcząca się na płaszczyźnie nauk przyrodniczych nie wynika ateizm. Również niektórzy teiści popełniają błąd, próbując wykazać istnienie Boga przez wskazanie jakichś jednostkowych zdarzeń, których zajścia nie wyjaśniają obecnie teorie przyrodnicze. $\mathrm{W}$ argumentacjach za istnieniem Boga odwołujących się do świata przyrody należałoby raczej rozpatrywać wszechświat jako pewną całość i rozpoznawać w nim piękno, celowość, racjonalność wyrażającą się w prawach przyrody, a więc wykorzystać globalne cechy wszechświata. W tym sensie można twierdzić, że stworzony wszechświat wskazuje na swego Stwórcę.

\section{BIBLIOGRAFIA}

Augustyn. Wyznania. Tłum. Zygmunt Kubiak. Warszawa: Pax, 1978.

Bene, Michael. Darwin's Black Box: The Biochemical Challenge to Evolution. New York: Free Press, 1996. Wyd. pol.: Czarna skrzynka Darwina - biochemiczne wyzwanie dla ewolucjonizmu. Warszawa: Megas, 2008.

BeHE, Michael. „Molecular Machines: Experimental Support for the Design Inference”. Cosmos Pursuit 1, nr 2 (1998): 27-35.

BeHE, Michael. „Design in the Details: The Origin of Biomolecular Machines”. W: Darwinism, Design and Public Education, red. John A. Campbell, Stephen C. Meyer, 287-302. East Lansing, MI: Michigan State University Press, 2003. 
BeHE, Michael. „Precyzyjny projekt: powstawanie biologicznych mechanizmów molekularnych”. Tłum. Dariusz Sagan. Na Poczatku ..., nr 5-6 (2004): 163-183. Dostęp 10.09.20019. http://www.nauka-a-religia.uz.zgora.pl/index.php/pl/przedruki/15-przedruki/391-pr-art-15.

Berry, Robert J. Bóg i biolog. Wiara a nauki przyrodnicze. Tłum. Jerzy Kochanowicz. Kraków: WAM, 2005.

Bylica, Piotr. „Levels of Analysis in Philosophy, Religion, and Science”. Zygon 50, nr 2 (2015): 304-328. doi:10.1111/zygo.12179.

BylicA, Piotr. Wspótczesny teizm naturalistyczny z punktu widzenia modelu poziomów analizy. Problem działania sfery nadnaturalnej w przyrodzie. Zielona Góra: Instytut Filozofii UZ, 2016.

Dawkins, Richard. Samolubny gen. Warszawa: Prószyński i S-ka, 1996.

Dembski, William. The Design Inference: Eliminating Chance through Small Probabilities. Cambridge: CUP, 1998.

Dembski, William. 2002. No Free Lunch: Why Specified Complexity Cannot Be Purchased without Intelligence. Lanham: Rowman \& Littlefield Publishers, 2002.

DemBski, William. „Powrót projektu do nauk przyrodniczych”, tłum. Dariusz Sagan. W: Teoria inteligentnego projektu, red. Kazimierz Jodkowski, 11-24. Warszawa: Megas, 2007.

Ditfurth, Hoimar von. Nie tylko z tego świata jesteśmy. Nauki przyrodnicze, religia i przyszłość człowieka. Tłum. Anna Danuta Tauszyńska. Warszawa: Pax, 1985.

Dobzhansky, Theodosius. "Biology, Molecular and Organismic". American Zoologist 4, nr 4 (1964): 443-452.

DzIK, Jerzy. Ewolucja. Warszawa, 2006. Dostęp 15.01.2020. http://www.paleo.pan.pl/people/Dzik/ Publications/Ewolucja_liceum.pdf.

FutuYma, Douglas. Ewolucja. Warszawa: Wydawnictwa UW, 2008.

Gould, Stephen J. Rocks of Ages. Science and Religion in the Fullness of Life. London: Vintage, 2001.

Gutowski, Piotr. „Czym jest «nowy ateizm»”. W: Nauki przyrodnicze a nowy ateizm, red. Marek Słomka, 7-45. Lublin: Wydawnictwo KUL, 2012.

IsAAK, Mark. „A Philosophical Premise of 'Naturalism'?”. talkdesign.org, 24.09.2002. Dostęp 15.01.2010. talkdesign.org/faqs/naturalism.html.

Jackelén, Antje. Time and Eternity. The Question of Time in Church, Science, and Theology. Philadelphia-London: Templeton Foundation Press, 2005.

JoDKowsKi, Kazimierz. „Klasyfikacja stanowisk kreacjonistycznych”. Filozoficzne Aspekty Genezy 2-3. Dostęp 25.05.2020. http://www.nauka-a-religia.uz.zgora.pl/index.php/pl/czasopismo/ 34-fag-2005-2006/601-fag-2005-2006-art-112007.

Jodkowski, Kazimierz. Spór ewolucjonizmu z kreacjonizmem. Podstawowe pojęcia i poglady. Warszawa: Megas, 2007.

JoDKowski, Kazimierz. „Zasadnicza nierozstrzygalność sporu ewolucjonizm-kreacjonizm”. Przegląd Filozoficzny - Nowa Seria 21, nr 3 (2012): 201-222.

JoDKowski, Kazimierz. „Czy nauka może wykryć inteligentny projekt?”. filozofiaprzyrody.pl, 30.12.2019. Dostęp 3.01.2020. https://www.filozofiaprzyrody.pl/czy-nauka-moze-wykrycinteligentny-projekt.

KLoskowski, Kazimierz. Filozofia ewolucji i filozofia stwarzania. T. 1-2. Warszawa: Wydawnictwo ATK, 1999. 
KŁóSAK, Kazimierz. 1980. Z teorii i metodologii filozofii przyrody. Poznań: Księgarnia Św. Wojciecha, 1980.

Lemańska, Anna. „Status metodologiczno-epistemologiczny koncepcji inteligentnego projektu”. W: Pogranicza nauki. Protonauka - paranauka - pseudonauka. Filozofia przyrody i nauk przyrodniczych 3, red. Józef Zon, 303-315. Lublin: Wydawnictwo KUL, 2008.

Mackey, James P. Christianity and Creation: The Essence of the Christian Faith and Its Future among Religions. New York: Continuum, 2006.

Paley, William. 1854. Natural Theology: or, Evidences of the Existence and Attributes of the Deity, Collected from the Appearances of Nature. Boston: Gould and Lincoln, 1854. Dostęp 23.12.2019. archive.org/details/naturaltheology01warwgoog.

Pedersen, Olaf. The Book of Nature. Vaticano: Vatican Observatory Publications, 1992.

SAGAN, Dariusz. „Teoria inteligentnego projektu a kreacjonizm”. Kwartalnik Filozoficzny 43, nr 2 (2015): 131-150.

SAGAN, Dariusz. Metodologiczno-filozoficzne aspekty teorii inteligentnego projektu. Zielona Góra: Instytut Filozofii UZ, 2015.

ŚwIEŻyŃski, Adam. „Nowożytne przemiany idei samorództwa”. Roczniki Filozoficzne 57, nr 1 (2009): 195-229.

TAX, Sol, Charles Callender, red. Evolution after Darwin. T. 3, Issues in Evolution. Chicago: University of Chicago Press, 1960.

Teilhard de Chardin, Pierre. Le phénomène humain. Paris: Éditions du Seuil, 1955. Wyd. pol.: Czlowiek i inne pisma. Warszawa: Pax, 1984.

Witham, Larry. By Design. Science and the Search for God. San Francisco: Encounter Books, 2003.

ZoN, Józef. „Kiedy «kreacja albo ewolucja» a kiedy «kreacja oraz ewolucja»”. W: Ewolucjonizm czy kreacjonizm, red. Piotr Jaroszyński i in., 275-302. Lublin: Fundacja Lubelska Szkoła Filozofii Chrześcijańskiej, 2008.

\section{KONFLIKT EWOLUCJONIZMU Z KREACJONIZMEM JAKO SPÓR ŚWIATOPOGLĄDOWY}

\section{Streszczenie}

Jednym ze współczesnych sporów światopoglądowych jest konflikt między materialistycznymi ewolucjonistami a zwolennikami projektu w przyrodzie. Co istotne, obie strony sporu twierdzą, że ich stanowiska mieszczą się w obszarze nauk przyrodniczych. Dyskusje toczą się już od ponad stu lat, lecz nie widać szans na ich zakończenie i uzyskanie jakiegoś konsensusu. Źródło takiego stanu rzeczy zdaje się leżeć w tym, że spór ten toczy się w rzeczywistości na płaszczyźnie filozoficznej.

$\mathrm{W}$ artykule przytaczam argumenty za tym, że zarówno ewolucjonizm materialistyczny, jak i koncepcja inteligentnego projektu nie są teoriami naukowymi. Porównuję także pojęcia ewolucji i kreacji oraz pokazuję, że pojęcie kreacji nie jest pojęciem naukowym. Stwarzanie bowiem jest aktem Stwórcy, który nie jest bytem czasoprzestrzennym. Jego działania zatem nie mogą być badane metodami właściwymi dla nauk przyrodniczych.

Słowa kluczowe: ewolucja; kreacja; Bóg; czas; wieczność; przestrzeń. 


\section{CONFLICT OF EVOLUTIONISM WITH CREATIONISM AS A WORLD-VIEW DISPUTE}

\section{Sum mary}

One of the contemporary world-view disputes is the conflict between materialistic evolutionists and proponents of the intelligent design. Importantly, both sides of the dispute claim that their positions fall within the area of natural sciences. Discussions have been going on for over a hundred years, but there is no chance that they will end and that there will be some consensus. The source of this state of affairs seems to lie in the fact that this dispute is taking place on a philosophical level.

In the article, I give arguments that both materialistic evolutionism and the concept of intelligent design are not scientific theories. I also compare the concepts of evolution and creation and show that the concept of creation is not a scientific concept. Creation is an act of the Creator who is not a space-time being. Therefore, his activities cannot be studied by methods appropriate to natural sciences.

Keywords: evolution; creation; God; time; eternity; space. 